\title{
GENETIC DIVERSITY OF KEJOBONG GOAT BASED ON MITOCHONDRIAL DNA D-LOOP SEQUENCE
}

\author{
M. F. Harlistyo, Sutopo and E. Kurnianto \\ Faculty of Animal and Agricultural Sciences, \\ Diponegoro University, Tembalang Campus, Semarang 50275 - Indonesia \\ Corresponding E-mail: kurniantoedy17@gmail.com
}

Received September 10, 2014; Accepted November 26, 2014

\begin{abstract}
ABSTRAK
Tujuan penelitian ini adalah untuk mengkaji keragaman genetik pada D-loop DNA mitokondria kambing Kejobong. Penelitian dilakukan dengan menggunakan sampel darah dari 12 ekor kambing Kejobong pada 4 lokasi yang berbeda di Kabupaten Purbalingga, Jawa Tengah yaitu di Kecamatan Kejobong, Pangadegan, Bukateja dan Kaligondang. DNA mitokondria (mtDNA) diekstraksi dari sampel darah. Hasil ekstraksi DNA diamplifikasi dengan metode PCR (Polymerase Chain Reaction) menggunakan primer forward (5-tcactatcagcacccaaagc-3') dan primer reverse (5' -ggcattttcagtgccttgct3'). Setelah dilakukan analisis sekuensing diperoleh nukleotida sepanjang $548 \mathrm{bp}$. Sekuen nukleotida tersebut kemudian disejajarkan dengan Capra hircus (no akses GenBank : KF9526011) dan ternyata terdapat 11 situs berbeda pada ruas D-loop mtDNA. Lima situs dapat digunakan sebagai penanda khusus untuk membedakan antara kambing Kejobong dengan Capra hircus yaitu pada situs ke 317 (A-G), 403 (T-C), 434 (T-C), 537 (C-T), dan 553 (A-G). Analisis ikatan nukleotida juga mendapatkan tujuh haplotype yang berbeda. Disimpulkan bahwa sebaran situs yang berbeda menunjukkan pola haplotype yang berbeda pada kambing Kejobong.
\end{abstract}

Kata kunci : keragaman genetik, kambing Kejobong, D-loop mitokondria

\begin{abstract}
This study was aimed to find out the diversity of mtDNA D-loop at Kejobong goat. The complete mtDNA D-loop sequence of 12 goat blood samples were analyzed from 4 different location in Purbalingga Regency, Central Java province, sub-districts Kejobong, Pangadegan, Bukateja, and Kaligondang. The mtDNA D-loop was extracted from blood sample. DNA obtained were amplified by PCR (Polymerase Chain Reaction) method using primers (5'-tcactatcagcacccaaagc-3') as forward and (5'-ggcatttcagtgccttgct-3') as reverse and subsequently sequenced. After nucleotide sequencing analysis conducted, 548 bp along was obtained. Nucleotides were then aligned with Capra hircus (GenBank Access No.: KF952601.1) and apparently there were 11 different sites on the segment of mtDNA Dloop. Five sites could be used as a specific marker to distinguish between the Capra hircus and Kejobong goat, namely at the site of 317 (A-G), 403 (T-C), 434 (T-C), 537 (C-T), and 553 (A-G). Nucleotide sequence analysis also contained seven different haplotypes. It was concluded that the distribution of the different sites showed different haplotype patterns in Kejobong goat.
\end{abstract}

Keyword : genetic diversity, Kejobong goat, mtDNA D-loop

\section{INTRODUCTION}

Kejobong Goat is one of Indonesian germplasm concentrated in Kejobong sub-district, Purbalingga regency, Central Java Province. In general, Kejobong goat have characteristics of black white or white black color body (Kurnianto et al., 2012). Some study have been done in Kejobong goat, included reproduction performance with flushing (Socheh et al., 2011) 
and cranium analysis (Suryani et al., 2013). However, study about mtDNA D (displacement)loop have not been done yet. Prawirodigdo et al. (2004) stated that further study is required for more detail about characteristics of Kejobong goat to elucidate the similarity or difference with other local goat of Indonesia.

The mtDNA D-loop was used to reveal the genetic diversity, phylogeny, and the animal domestication (He et al., 2008; Zeder, 2008; Sulandari dan Zein, 2009; Abdullah et al., 2008). Study about mtDNA D-loop in Indonesia have been done by Batubara et al. (2009) in six local goat Indonesia and Oka et al. (2011) in Gembrong goat. The mtDNA D-loop analysis can describe the lineage of local goat. Lineage was devided in 6 haplogroups in which each haplogroup has high genetic diversity (Naderi et al., 2007). Luikart et al. (2001) and Joshi et al. (2004) devided the lineage of goat into 3 haplogroups and 4 haplogroups, respectively.

Kejobong goat genetic resources could be lost if there is no conservation effort. It can be occurs due to the increasing number of crossbreed with other local goats. The purpose of this study was to find out the diversity of mtDNA D-loop in Kejobong goat.

\section{MATERIALS AND METHODS}

\section{Material}

A total of twelve blood samples of Kejobong goats were taken from four different sub-districts location in Purbalingga Regency, Central Java Province, these were Kejobong, Pangadegan, Bukateja and Kaligondang. Purposive sampling method was applied to determine the location of study on the basis of population density of Kejobong goat. Chemical reagents used to extract DNA were RBC (Red Blood Cell) Lysis Buffer, Proteinase-K, GT Buffer, GB (Guanidin Buffer), W1 Buffer, Wash Buffer and Elution Buffer. Agarose gel was made of agarose powder, buffer $1 \mathrm{x}$ TBE and Floro Safe DNA Stain. PCR was performed using KAPA (Kit PCR), $\mathrm{dH}_{2} \mathrm{O}$ free nuclease, loading dye and DNA ladder.

\section{Laboratory Procedure}

DNA analysis was conducted in Faculty of of Veterinary Medicine, Gadjah Mada University. DNA was extracted using Gene Aid kit following the manufacturer's instructions. DNA extraction was used as PCR template. Primers were designed using Primer3Plus, the primers sequences were (5'-tcactatcagcacccaaagc-3') as forward primer and (5'-ggcattttcagtgcettgct-3') as reverse primer. PCR process was performed with condition predenaturation at $94^{\circ} \mathrm{C}$ for 5 minutes, denaturation at $94^{\circ} \mathrm{C}$ for 30 seconds, annealing at $51^{\circ} \mathrm{C}$ for 45 seconds, elongation (extension) at $72^{\circ} \mathrm{C}$ for 1 minute and post elongation at $72^{\circ} \mathrm{C}$ for 5 minutes. PCR was repeated for 35 cycles for optimum result (Purwantini et al., 2013). PCR product was separated by electrophoresis agarose gel $1 \%$ using buffer 1x TBE in Submarine Electrophoresis (Hoefer, USA). UV light $(\lambda=300 \mathrm{~nm})$ was used to observe the electrophoresis result. PCR product was packaged and sent to ${ }^{\text {st }}$ Base Asia-Malaysia via PT. Genetika Science Indonesia for sequencing process.

Sequenced products were edited for correction and analyzed using MEGA (Molecular Evolution Genetic Analysis) 5.0 software. D-loop sequence was aligned with ClustalW program and compared to the reference sequence of Capra hircus from GenBank (NCBI) with no access KF952601.1. In order to construct phylogeny tree we used Capra sibirica (FJ207529.1),Capra pyrenaica (FJ207528.1), Capra nubiana (FJ207527.1), Capra ibex (FJ207526.1), Capra Falconeri (FJ207525.1) as reference and Bos indicus as outgroup. Phylogeny was constructed by using Unweighted Pair-Group Method With Arithmetic Mean (UPGMA) with NeighbourJoining and 2 parameter Kimura method. Phylogeny test used Bootstrap method with 1000 replication (Tamura et al., 2011).

\section{RESULTS AND DISCUSSION}

D-loop mtDNA fragment was succesfully amplified using PCR technique, obtained along as 1213 bp (bases pair), located between tRNA ${ }^{\text {Pro }}$ and tRNA $^{\text {Phe }}$ gene. Result of amplified D-loop mtDNA fragment and D-loop scheme are presented in Figure 1 and Figure 2. Unfortunately, one sampel was excluded from data due to error in sequence. All samples were alignment with reference sequence (Capra hircus : KF9526011) and obtained $548 \mathrm{bp}$ lenght sequences which located between site number 62 and 610 of Dloop.

As much as eleven nucleotide subtitutions were found. Five subtitutions site were used as specific marker for differentiation between Kejobong goat and Capra hircus. Those five subtitutions sites were 317(A-G), 403(T-C), 434(T-C), 537(C-T). The five subtitutions were 


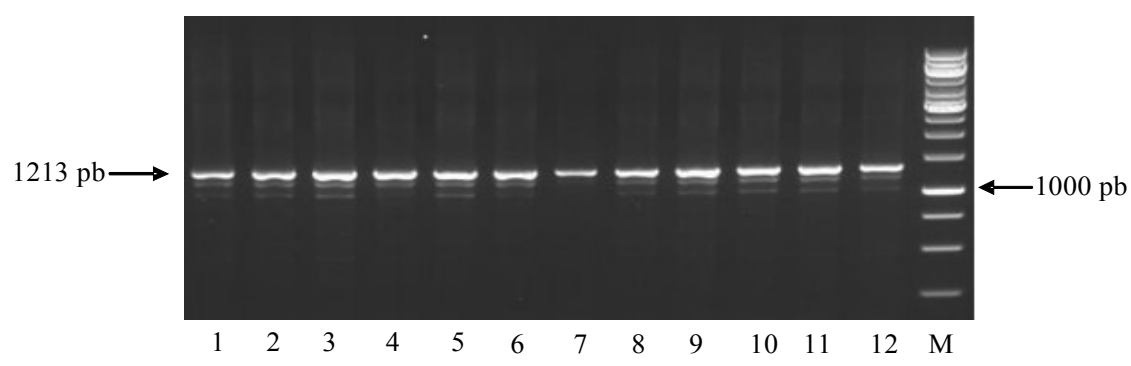

Figure 1. Product of PCR D-Loop at Kejobong goat. 1-12: samples; M: DNA Ladder of $1 \mathrm{~kb}$.

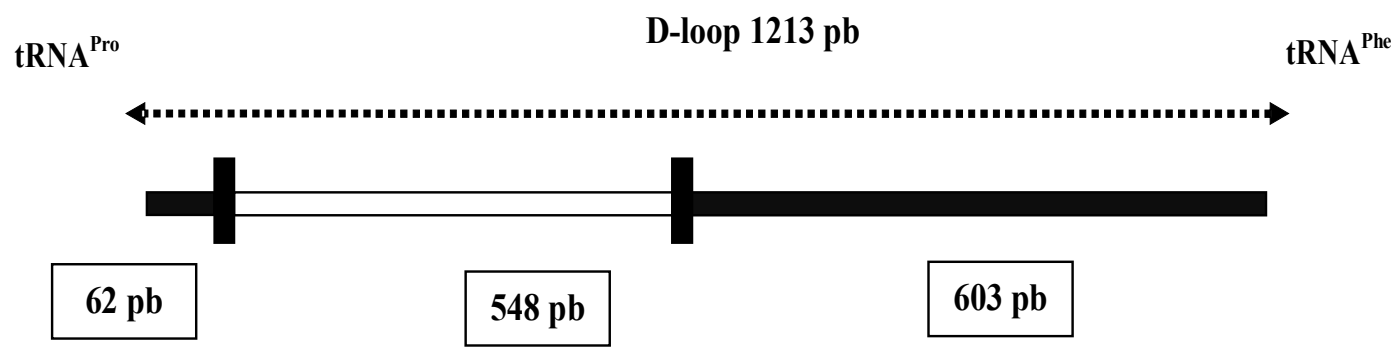

Figure 2. D-Loop Kejobong Goat Amplified Scheme. White and black parts are analyzed and did not analyzed area, respectively

Table 1. Diversity of D-loop Kejobong Goat Nucleotide with Capra hircus reference (KF952601.1) from GenBank

\begin{tabular}{|c|c|c|c|c|c|c|c|c|c|c|c|}
\hline \multirow{2}{*}{ Sample Name } & \multicolumn{11}{|c|}{ Site Number } \\
\hline & 317 & 403 & 434 & 457 & 480 & 483 & 537 & 543 & 553 & 562 & 607 \\
\hline Capra hircus & A & $\mathrm{T}$ & $\mathrm{T}$ & $\mathrm{C}$ & $\mathrm{T}$ & A & $\mathrm{C}$ & A & A & A & $\mathrm{T}$ \\
\hline KJB 1 & $\mathrm{G}$ & $\mathrm{C}$ & $\mathrm{C}$ & $*$ & $*$ & $*$ & $\mathrm{~T}$ & G & $\mathrm{G}$ & $*$ & $*$ \\
\hline KJB 2 & $*$ & $*$ & $*$ & $*$ & $\mathrm{C}$ & $*$ & * & * & * & $\mathrm{G}$ & $*$ \\
\hline KJB 3 & $*$ & $*$ & $*$ & $*$ & $*$ & $\mathrm{G}$ & $*$ & $*$ & $*$ & $\mathrm{G}$ & $*$ \\
\hline KJB 4 & $*$ & $*$ & $*$ & $*$ & $*$ & $*$ & $*$ & $*$ & $*$ & $\mathrm{G}$ & $*$ \\
\hline KJB 5 & $*$ & $*$ & $*$ & $*$ & $*$ & G & $*$ & $*$ & $*$ & $\mathrm{G}$ & $*$ \\
\hline KJB 6 & $*$ & $*$ & $*$ & $\mathrm{~T}$ & $*$ & $*$ & $*$ & $*$ & $*$ & $\mathrm{G}$ & $*$ \\
\hline KJB 7 & $*$ & $*$ & $*$ & $\mathrm{~T}$ & $*$ & $*$ & $*$ & $*$ & $*$ & $\mathrm{G}$ & $*$ \\
\hline KJB 8 & $*$ & $*$ & $*$ & $*$ & $\mathrm{C}$ & $*$ & $*$ & $*$ & $*$ & $\mathrm{G}$ & $*$ \\
\hline KJB 9 & $*$ & $*$ & $*$ & $*$ & $*$ & $*$ & $*$ & A & $*$ & $\mathrm{G}$ & $\mathrm{C}$ \\
\hline KJB 10 & $*$ & $*$ & $*$ & * & $*$ & $*$ & * & $*$ & $*$ & G & $\mathrm{C}$ \\
\hline KJB 11 & $*$ & $*$ & $*$ & $*$ & $*$ & $*$ & $*$ & $*$ & $*$ & $\mathrm{G}$ & $*$ \\
\hline
\end{tabular}

KJB: Kejobong goat sample name), A (Adenin), G (Guanin), C (Cytosin) and T (Timin). 
transition subtitution. Transition subtitution was occured between one of pirimidin base with other pirimidin base or one of purin base with other purin base, e.g. Adenin with Guanin or Timin with Cytosin. Diversity of D-loop Kejobong goat is presented in Table 1. Batubara et al. (2011) described all about six local Indonesian goat and found subtitution nucleotide while aligned with Capra hircus. Nucleotide subtitution in this case was assumed due to effect of environment where goat lived and production purpose.

From the sequence analysis result, seven haplotypes were found among Kejobong goat at different area. Seven haplotypes Kejobong goat is presented in Table 2. Genetic distance value between Kejobong goat and Capra hircus around 0.011-0.015, in which the value indicated a close relationship between Kejobong goat and Capra hircus. Among Kejobong goats, the highest genetic distance value was only 0.006 (Table 3 ). Philogeny tree contruction in Figure 3 showed the position of Kejobong goat, the Capra and Bos indicus as the outgroup. The philogeny tree ilustrated that Kejobong and Capra hircus were in different branch. Bootstraps value showed about 99\% indicating Kejobong goat and Capra hircus had difference in nucleotide sequence. According to Indi Dharmayanti (2011), bootstraps value showed significance of phylogeny. Bootstraps value among Kejobong goat around 13-68\% indicating Kejobong goat had no difference in nucleotide sequence. Its was occured because sample Kejobong goat is from one location close to each other, so had possibility Kejobong goat is from one maternal. Batubara et al. (2011) explained that Boer and Jawarandu goat have low bootstraps value about $30 \%$ and $38-65 \%$, respectively, that showed closeness of genetic relationship.

Table 2. Haplotype of Kejobong Goat.

\begin{tabular}{cc}
\hline Haplotype & Sample \\
\hline 1 & KJB 1 \\
2 & KJB 2 and KJB 8 \\
3 & KJB 3 and KJB 5 \\
4 & KJB 4 and KJB 11 \\
5 & KJB 6 and KJB 7 \\
6 & KJB 9 \\
7 & KJB 10 \\
\hline
\end{tabular}

Table 3. Genetic Distance of Kejobong Goat with Capra hircus Reference (KF952601.1) from GenBank.

\begin{tabular}{|c|c|c|c|c|c|c|c|c|c|c|c|c|}
\hline $\begin{array}{l}\text { Name of } \\
\text { Sample }\end{array}$ & $\begin{array}{l}\text { Capra } \\
\text { Hircus }\end{array}$ & KJB 1 & KJB 2 & KJB 3 & KJB 4 & KJB 5 & KJB 6 & KJB 7 & KJB 8 & KJB 9 & KJB 10 & KJB 11 \\
\hline Capra hircus & 0.000 & & & & & & & & & & & \\
\hline KJB 1 & 0.011 & 0.000 & & & & & & & & & & \\
\hline KJB 2 & 0.015 & 0.004 & 0.000 & & & & & & & & & \\
\hline KJB 3 & 0.015 & 0.004 & 0.004 & 0.000 & & & & & & & & \\
\hline KJB 4 & 0.013 & 0.002 & 0.002 & 0.002 & 0.000 & & & & & & & \\
\hline KJB 5 & 0.015 & 0.004 & 0.004 & 0.000 & 0.002 & 0.000 & & & & & & \\
\hline KJB 6 & 0.015 & 0.004 & 0.004 & 0.004 & 0.002 & 0.004 & 0.000 & & & & & \\
\hline KJB 7 & 0.015 & 0.004 & 0.004 & 0.004 & 0.002 & 0.004 & 0.000 & 0.000 & & & & \\
\hline KJB 8 & 0.015 & 0.004 & 0.000 & 0.004 & 0.002 & 0.004 & 0.004 & 0.004 & 0.000 & & & \\
\hline KJB 9 & 0.013 & 0.006 & 0.006 & 0.006 & 0.004 & 0.006 & 0.006 & 0.006 & 0.006 & 0.000 & & \\
\hline KJB 10 & 0.015 & 0.004 & 0.004 & 0.004 & 0.002 & 0.004 & 0.004 & 0.004 & 0.004 & 0.002 & 0.000 & \\
\hline KJB 11 & 0.013 & 0.002 & 0.002 & 0.002 & 0.000 & 0.002 & 0.002 & 0.002 & 0.002 & 0.004 & 0.002 & 0.000 \\
\hline
\end{tabular}




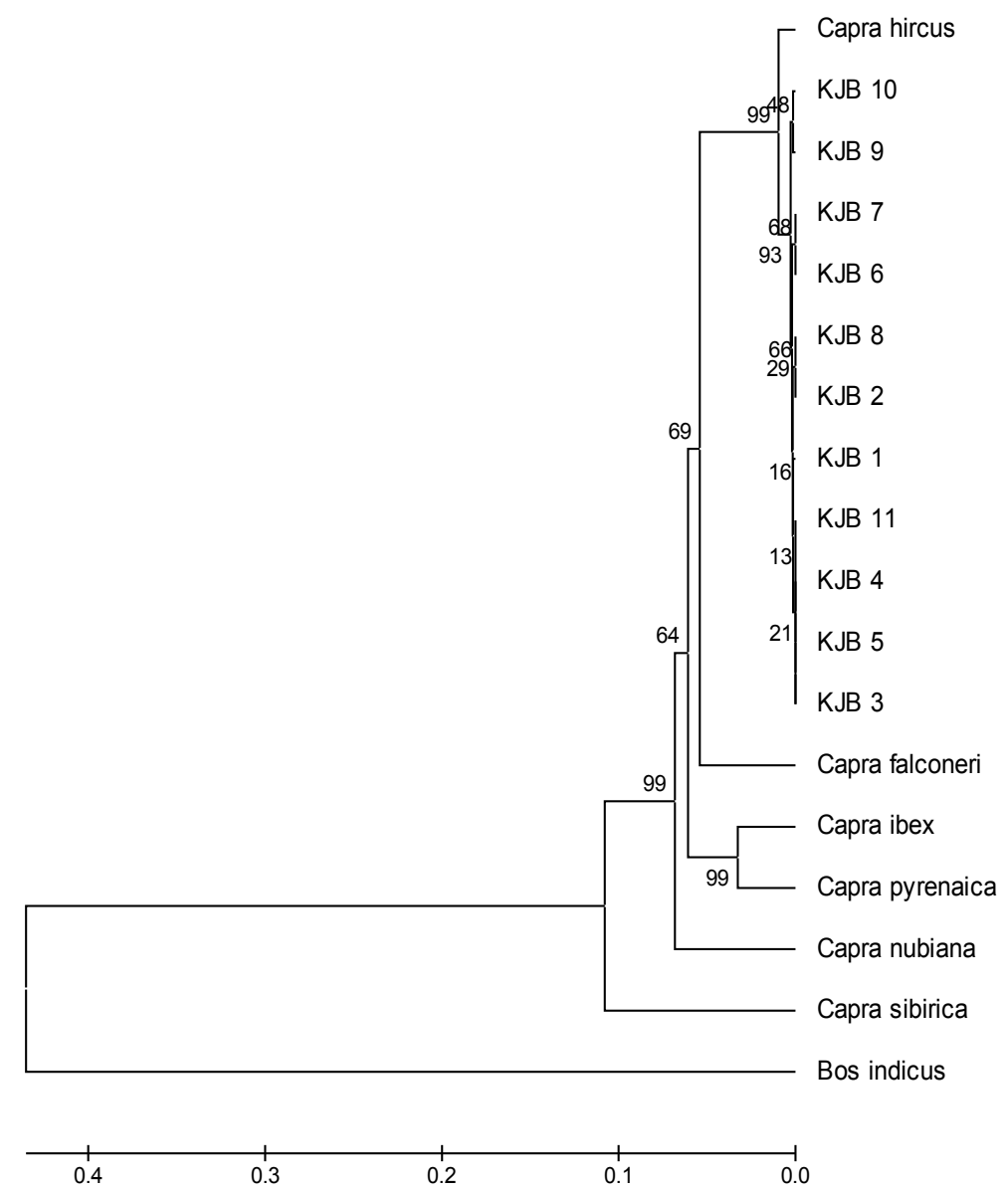

Figure 3. Phylogeny Tree of Kejobong goat, Other Capra and Bos indicus

\section{CONCLUSION}

There are no significance differerences among Kejobong goats but have specific site of nucleotide compared to Capra hircus in different branch with bootstraps value $99 \%$.

\section{ACKNOWLEDGMENT}

The authors would like to express the gratitude to the Head of Animal Husbandry Office and their staffs at Purbalingga Regency for permiting of the research and for gathering data, Suparni, S.Pd for all research support in Kejobong, Dr. drh. Rini Widayanti, M.P. for guiding laboratory research and Kejobong Research Team (Ono, Faruq, Zulkarnain, Aji, Hasna, and Tis'a) for the teamwork. This research was funded by Badan Penelitian Pengembangan Propinsi Jawa Tengah via Research Unggulan Daerah 2013.

\section{REFERENCES}

Abdullah, M. A. N., R. R. Noor and E. Handiwirawan. 2008. Genetic marker identification of Aceh cattle using D-loop region analysis. J. Indonesian Trop. Anim. Agric. 33(1):1-10

Batubara, A., R.R. Noor, A. Farajallah, B. Tiesnamurti and M. Doloksaribu. 2011. Karakterisasi molekuler enam subpopulasi kambing lokal Indonesia berdasarkan analisis sekuen daerah D-loop DNA mitokondria. Jurnal Ilmu Ternak dan Veteriner. 16(1):49-60

He, D. Q., Q. Zhu, S. Y. Chen, H. Y. Wang, Y. P. Liu and Y. G. Yao. 2008. A homogenous nature of native Chinese duck matrilineal pool. BMC Evolutionary Biology. 8:298

Indi Dharmayanti, N.L.P. 2011. Filogenetika molekuler: metode taksonomi organisme berdasarkan sejarah evolusi. Wartazoa. 


$$
\text { 21(1):1-10 }
$$

Joshi, M. B., P. K. Rout, A. K. Mandal, C. TylerSmith, L. Singh and K. Thangaraj. 2004. Phylogeography and origin of Indian domestic goats. Mol. Biol. Evol. 21(3):454462

Kurnianto, E., Sutopo and E. Purbowati. 2012. Penampilan Fenotipik dan Genotipik Kambing Kejobong. Badan Penerbit Universitas Diponegoro.

Luikart, G., L. Gielly, L. Excoffier, J. D. Vigne, J. Bouvet and P. Taberlet. 2001. Multiple maternal origins and weak phylogeographic structure in domestic goats. Proc. Natl. Acad. Sci. 98(10):5927-5932

Naderi, S., H. R. Rezaei, P. Taberlet, S. Zundel, S. A. Rafat, H. R. Naghash, M. A. A. ElBarody, O. Ertugrul and F. Pompanon. 2007. Large-scale mitochondrial DNA analysis of the domestic goat reveals six haplogroups with high diversity. PLoS ONE. 2(10):e1012

Prawirodigdo, S., T. Herawati and B. Utomo. 2004. Penampilan peternakan kambing dan potensi bahan pakan lokal sebagai komponen pendukungnya di Wilayah Propinsi Jawa Tengah. Prosiding, Lokakarya Nasional Kambing Potong. 6-8 Agustus 2004, Bogor. p. 157-163

Purwantini, D, T. Yuwanta, T. Hartatik and Ismoyowati. 2013. Polymorphism of D-loop Mitochondria DNA region and phylogenetic in five Indonesian native duck population. Int. J. Poult. Sci. 12(1):55-63

Socheh, M., Ismaya, I.G.S. Budisatria and Kustantinah. 2011. Pengaruh flushing berbasis pakan lokal terhadap pertumbuhan dan birahi kambing Kejobong betina dewasa. Sains Peternakan. 9(2):53-64

Sulandari, S. and M. S. A. Zein. 2009. Analysis of D-loop mitochondrial DNA to investigate the position of red jungle fowl in the domestication chicken in Indonesia Med. Pet. 32:31-39

Suryani, H. F., E. Purbowati and E. Kurnianto. 2013. Multivariate analysis on cranium measurements of three breeds of goat in central java. J. Indonesian Trop. Anim. Agric. 38(4) : 217-224

Oka, I. G. L., W. S. Yupardhi, I. B. Bantra, N. Suyasa and A. A. S. Dewi. 2011. Genetic relationship between Gembrong goat, Kacang goat and Kacang $\mathrm{X}$ Etawah crossbred (PE) based on their mitochondrial DNA. J. Veteriner. 12(3):180-184

Tamura, K., D. Peterson, N. Peterson, G. Stecher, M. Nei and S. Kumar. 2011. MEGA 5: Molecular evolutionary genetics analysis using maximum likelihood, evolutionary distance, and maximum parsimony methods. Mol. Biol. Evol. 28(10):2731-2739.

Yuriadi, R. Widayanti, A. Haryanto and W. T. Artama. 2009. Kajian molekuler daerah Dloop Parsial DNA mitokondria kuda (Equus caballus) asli Priangan. J. Sain. Vet. 27(2):67-74

Zeder, M. A. 2008. Domestication and early agriculture in the Mediterranean Basin: Origins, diffusion, and impact. Proc. Natl. Acad. Sci. 105(33):11597-1604 